\title{
Acetylcholine Attenuated TNF- $\alpha$-Induced Apoptosis in H9c2 Cells: Role of Calpain and the p38-MAPK Pathway
}

\author{
Ming Zhao ${ }^{\mathrm{a}}$ Yang Yang ${ }^{\mathrm{a}}$ Xueyuan $\mathrm{Bi}^{\mathrm{a}}$ Xiaojiang $\mathrm{Yu}^{\mathrm{a}}$ Hanghuan Jia ${ }^{\mathrm{a}}$ Huanle Fang ${ }^{\mathrm{b}}$ \\ Weijin Zanga
}

aDepartment of Pharmacology, Xi'an Jiaotong University Health Science Center, Xi'an, 'Department of Pharmacology, Xi'an Peihua University, Xi'an, P.R.China

\section{Key Words}

Acetylcholine $\cdot$ Muscarinic receptor $•$ Calpain $•$ Calpastatin $•$ p38-MAPK $•$ Apoptosis

\begin{abstract}
Background: Previous studies have shown that inflammation is associated with excessive activation of calpains. Acetylcholine (ACh) has been reported to inhibit pro-inflammatory cytokine release and protect against cardiomyocyte injury. However, there is no direct evidence regarding whether $\mathrm{ACh}$ can regulate calpains to exert cardioprotection. To this end, we investigated the effect of ACh on tumour necrosis factor alpha (TNF- $\alpha$ )-induced cardiomyocyte injury and further explored the underlying mechanism. Methods: Flow cytometry and transmission electron microscopy were performed to evaluate apoptosis and cellular ultrastructure. Western blotting was performed to assess changes in protein expression. siRNA was employed to silence specific proteins. Results: TNF- $\alpha$ treatment increased the expression of cleaved caspase-3, calpain-1 and p38-mitogen-activated protein kinase (p38MAPK). The calpain inhibitor PD150606 and the p38-MAPK inhibitor SB203580 inhibited apoptosis induced by TNF- $\alpha$. Moreover, SB203580 decreased the expression and activity of calpain-1, possibly related to the up-regulation of calpastatin. ACh significantly inhibited TNF- $\alpha$-induced cell apoptosis, as evidenced by decreases in caspase- 3 cleavage, p38-MAPK phosphorylation, and calpain-1 expression and activity as well as increases in calpastatin expression. These beneficial effects of $A C h$ were abolished by atropine or $M_{2} A C h R$ siRNA. Conclusion: Our results suggest that ACh ameliorated TNF- $\alpha$-induced calpain activation by decreasing p38-MAPK phosphorylation and enhancing calpastatin expression, indicating that calpain may be an important link between inflammatory factors and myocardial cell apoptosis.
\end{abstract}

M. Zhao and Y. Yang contributed equally to this work.

Prof. Wei-Jin Zang

KARGER 125
P.O. Box 77\#, No.76 Yanta West Road, Department of Pharmacology, Xi'an Jiaotong University Health Science Center, Xi'an 710061 (P.R. China)

Tel. +86-29-82655150, Fax +86-29-82655150, E-Mail zwj@mail.xjtu.edu.cn 


\section{Cellular Physiology Cell Physiol Biochem 2015;36:1877-1889 \begin{tabular}{l|l} 
and Biochemistry Publisned onIIne: July 13, 2015 & $\begin{array}{l}\text { C) 2015 S. Karger AG, Basel } \\
\text { www.karger.com/cpb }\end{array}$ \\
\hline
\end{tabular} \\ Zhao et al.: ACh Reduced Apoptosis via Calpain Regulation}

\section{Introduction}

Tumour necrosis factor-alpha (TNF- $\alpha$ ), a well-known inflammatory cytokine, is an important factor in the pathogenesis of cardiovascular injury [1]. Previous studies have shown that TNF- $\alpha$ production was elevated after exposure to hypoxia in H9c2 cardiomyocytes [2]. In patients with acute myocardial infarction (AMI), the plasma level of TNF- $\alpha$ increased, which could be a marker of cell death and recurrent ischaemia following AMI [3]. In a largeanimal study, coronary microembolization increased infarction size and TNF- $\alpha$ expression in the myocardium [4]. Therapeutic approaches blocking TNF- $\alpha$ production might have prophylactic value against secondary myocardial ischaemic injury; such an approach may reduce myocardial infarction and improve cardiac function, accompanied by a decrease in cardiomyocyte apoptosis [5].

Several lines of evidence suggest that vagus nerve stimulation (VNS) decreases infarct size and inflammation marker expression and prevents myocardial remodelling induced by ischaemia/reperfusion (I/R) [6]. Additionally, acetylcholine (ACh) elicits an anti-apoptotic effect through the activation of the muscarinic ACh receptor (MAChR) and the activation of anti-oxidant systems [7]. Previous studies in our lab have found that ACh protects cardiomyocytes by reducing TNF- $\alpha$ production in both post-infarction hearts and cultured H9c2 cells exposed to hypoxia [8]. Interestingly, Bajaj and Sharma showed that calpain inhibition suppressed TNF- $\alpha$-induced apoptosis in a cardiac muscle cell line [9]. However, the effects of ACh on the impact of calpain activity and the balance of the calpain/calpastatin system are not yet fully understood.

Calpains are a family of calcium-dependent cysteine proteases with pro-apoptotic properties in the context of $\mathrm{Ca}^{2+}$ overload $[10,11]$. The myocardium contains modest amounts of the ubiquitous calpain-1 and calpain-2, which are present in the cytosol as inactive proenzymes [12]. Excessive calpain activity plays a critical role in mitochondrial damage and oxidative phosphorylation during cardiac I/R injury [13] and vascular injury in diabetics [14]. Several other studies have also demonstrated that the inhibition of calpain activity during I/R may reduce apoptosis and infarct size [15]. In addition, calpain is also specifically controlled by the endogenous inhibitor calpastatin. Over-expression of calpastatin inhibits calpain- 1 and calpain-2 activity in vitro. A recently report showed that calpains increased apoptosis, and calpastatin had the opposite effect [16]. Obviously, calpain inhibition may represent a new avenue for modulating damage to the heart. In this study, we aimed to investigate the effect of ACh on TNF- $\alpha$-induced apoptosis and the role of calpain in cardiomyocytes. The inhibition of the p38-mitogen-activated protein kinase (p38-MAPK) signalling pathway as a potential mechanism mediated by ACh was also examined.

\section{Materials and Methods}

\section{Materials}

ACh, atropine, SB203580 and PD150606 were purchased from Sigma-Aldrich (St. Louis, MO, USA). Glyceraldehyde-3-phosphate dehydrogenase (GAPDH), calpain-1, calpastatin, p38-MAPK, phosphorylated p38-MAPK, caspase-3, Bcl-2 and Bax primary antibodies were obtained from Cell Signaling Technology Inc. (Danvers, MA, USA). Infrared secondary antibodies were purchased from Odyssey (Li-Cor Biosciences, Lincoln, NE, USA). The calpain activity assay kit was purchased from Genmed Scientifics Inc. (Wilmington, DE, USA). Drug concentrations are expressed as their final molar concentrations within the culture dish.

Cardiomyocyte culture and treatment protocol

$\mathrm{H} 9 \mathrm{c} 2$ cells, which are derived from rat embryonic ventricular cardiomyocytes, were seeded at $1 \times 10^{5}$ cells $/ \mathrm{cm}^{2}$ in 6-well plates with high-glucose Dulbecco's modified Eagle's medium (DMEM) supplemented with $10 \%$ foetal bovine serum (FBS) and were cultured in a $5 \% \mathrm{CO}_{2}$ incubator at $37^{\circ} \mathrm{C}$.

The day after the cells were seeded, the cardiomyocytes were starved in FBS-free DMEM for $6 \mathrm{~h}$ and were then randomly divided into the following four groups: (1) control group (C): cardiomyocytes 


\section{Cellular Physiology Cell Physiol Biochem 2015;36:1877-1889 \begin{tabular}{l|l|l} 
DOI: 10.1159/000430157 & (C)15 S. Karger AG, Basel
\end{tabular} and BiOChemistry Publisned onlıne: July 13, $2015 \quad$ www.karger.com/cpb \\ Zhao et al.: ACh Reduced Apoptosis via Calpain Regulation}

continuously cultured for $12 \mathrm{~h}$ in FBS-free DMEM; (2) TNF- $\alpha$ group (T): cardiomyocytes treated with 20 $\mathrm{ng} / \mathrm{mL}$ TNF- $\alpha$ for $12 \mathrm{~h}$; (3) ACh group (A): cardiomyocytes treated with $10^{-6} \mathrm{~mol} / \mathrm{L}$ ACh for $14 \mathrm{~h}$; and (4) ACh pre-treatment group (A+T): cardiomyocytes pre-incubated with $10^{-6} \mathrm{~mol} / \mathrm{L}$ ACh for $2 \mathrm{~h}$ and then coincubated with ACh and TNF- $\alpha$ for $12 \mathrm{~h}$. All drugs were dissolved in pre-warmed FBS-free DMEM and were added directly to the cardiomyocytes. In the control groups, equivalent volumes of medium were added.

\section{Assessment of apoptosis}

Apoptosis was evaluated using flow cytometry. Apoptotic and necrotic cells were double-stained with annexin V and propidium iodide (PI). At the end of the experiment, cells grown adherently were gently mechanically detached and resuspended in $100 \mu \mathrm{L}$ binding buffer. Subsequently, the cells were incubated for 15 min in the dark with $5 \mu \mathrm{L}$ Annexin V and $100 \mu \mathrm{L}$ PI solution (BD PharMingen, San Diego, CA) at $25^{\circ} \mathrm{C}$, and then $400 \mu \mathrm{L}$ of binding buffer was added. Flow cytometry analysis was performed using a FACScan flow cytometer (Becton Dickinson, Heidelberg, Germany) equipped with a 488-nm argon laser. The CellQuest software (Becton Dickinson) was used for data acquisition.

\section{Cell survival assay}

Cell viability was examined using a 3-(4,5-dimethylthiazol-2-yl)-2,5-diphenyltetrazolium bromide (MTT; Sigma, St. Louis, MO) assay. At the end of the experiment, the cells were incubated in the MTT solution $(0.5 \mathrm{mg} / \mathrm{mL})$ for $4 \mathrm{~h}$ at $37^{\circ} \mathrm{C}$ and were then solubilized with $150 \mu \mathrm{L}$ DMSO. The absorbance was read at 492 $\mathrm{nm}$ using a multi-well scanning spectrophotometer. Cells in the control group were considered to be $100 \%$ viable.

Transmission electron microscopy (TEM)

Harvested cells were fixed with $2.5 \%$ glutaraldehyde and $4 \%$ paraformaldehyde in $0.1 \mathrm{~mol} / \mathrm{L}$ phosphate buffer ( $\mathrm{pH} 7.2-7.4$ ) for $2 \mathrm{~h}$ at $4^{\circ} \mathrm{C}$, embedded in propylene oxide and epoxy resin overnight at $37^{\circ} \mathrm{C}$, and then embedded and cut into ultrathin sections (1-2 $\left.\mu \mathrm{m}\right)$, double-stained with uranyl acetate and lead citrate, and examined by electron microscopy (H-7650; HITACHI, Japan). Technical support and materials were provided by the electron microscopy centre of Xi'an Jiaotong University.

\section{Caspase-3 activity assay}

Caspase- 3 activity was determined using the caspase- 3 activity assay kit (Bestbio, Shanghai, China). Cells were harvested and extracted on ice in lysis buffer for $15 \mathrm{~min}$. The lysates were centrifuged for $5 \mathrm{~min}$ at $500 \times \mathrm{g}$, and the supernatants were assessed for protein content. Subsequently, supernatant samples containing $50 \mu \mathrm{g}$ protein were incubated with $90 \mu \mathrm{L}$ reaction buffer and $10 \mu \mathrm{L}$ caspase- 3 substrate (containing $40 \mu \mathrm{mol} / \mathrm{L} \mathrm{N}$-acetyl-Asp-Glu-Val-Asp-p-nitroanilide) at $37^{\circ} \mathrm{C}$ for $2 \mathrm{~h}$ in the dark. The OD values were measured at $405 \mathrm{~nm}$ with a spectrophotometer.

\section{Calpain activity assay}

Calpain activity was assayed using the Calpain Activity Assay kit (Genmed Scientifics Inc., Wilmington, DE, USA). Briefly, cells were suspended in $50 \mu \mathrm{L}$ of extraction buffer on ice for $30 \mathrm{~min}$ and then centrifuged at $10,000 \times \mathrm{g}$ for $5 \mathrm{~min}$ at $4^{\circ} \mathrm{C}$. The cell lysates $(\sim 50 \mu \mathrm{g})$ were then diluted in extraction buffer, which contained reaction buffer and calpain substrate. The samples were incubated at $37^{\circ} \mathrm{C}$ for $1 \mathrm{~h}$, and the absorbance of each sample was read in a fluorescence spectrometer equipped with a $360-\mathrm{nm}$ excitation filter and a 520nm emission filter (POLARstar Omega and FLUOstar Omega microplate readers, BMG Labtech, Germany).

\section{Western Blotting}

The cardiomyocytes were prepared for immunoblotting as described previously [17]. The protein concentration was quantified using the bicinchoninic acid (BCA) protein assay (Beyotime Biotechnology, Jiangsu, China). Proteins (30 $\mu \mathrm{g} / \mathrm{lane}$ ) were separated by sodium dodecyl sulfate (SDS)-polyacrylamide gel electrophoresis and then electrotransferred to polyvinylidene difluoride membranes. The membranes were incubated with primary antibodies at $4^{\circ} \mathrm{C}$ overnight and then incubated with IRDye 800CW secondary antibodies for $45 \mathrm{~min}$ at room temperature. The bands were then visualized with an Odyssey infraredimaging system (Li-Cor Biosciences, Lincoln, NE, USA) and quantified by scanning densitometry.

\section{KARGER}




\section{Cellular Physiology Cell Physiol Biochem 2015;36:1877-1889 \begin{tabular}{l|l|l} 
DOI: 10.1159/000430157 & O 2015 S. Karger AG, Basel
\end{tabular}

SiRNA knockdown of $M_{2} A C h R$

Small interfering RNA (siRNA) was performed to knock down $\mathrm{M}_{2} \mathrm{AChR}$ in H9c2 cells. The siRNA oligonucleotides were synthesized by GenePharma Co. Ltd (Shanghai, China). The siRNA sequence targeting $\mathrm{M}_{2} \mathrm{AChR}$ is as follows: 5'-GUGCUCAUCAAUACUUUCUTTAGAAAGUAUUGAUGAGCACTT-3'. A scrambled nontarget siRNA was also used as a negative control. The detailed method was described previously [18]. Transfections were performed with $100 \mathrm{nM}$ of each siRNA using TurboFect siRNA Transfection Reagent (Thermo Fisher Scientific, Cleveland, OH, USA) according to the manufacturer's instructions. Forty-eight hours after transfection, the efficiency of siRNA-mediated $\mathrm{M}_{2} \mathrm{AChR}$ knockdown was determined by Western blotting.

\section{Statistical analysis}

All results are expressed as means \pm SEM. $\mathrm{P}<0.05$ was considered statistically significant. Comparisons of the results were performed one-way ANOVA followed by Tukey's post hoc test or Student's t test using SPSS 11.5 for Windows (SPSS Inc., Chicago, IL, USA). All Fig.s were prepared using GraphPad Prism 5.0 (GraphPad Software Inc., La Jolla, CA, USA).

\section{Results}

TNF- $\alpha$ promoted cell apoptosis in H9c2 cells

H9c2 cells were treated with various concentrations of TNF- $\alpha$ (2.5- $40 \mathrm{ng} / \mathrm{mL}$ ) for 12 h, which was consistent with a previous study [19]. As shown in Fig. 1A, ultrastructural analysis of the cardiomyocytes indicated that cells treated with TNF- $\alpha$ for $12 \mathrm{~h}$ began to show

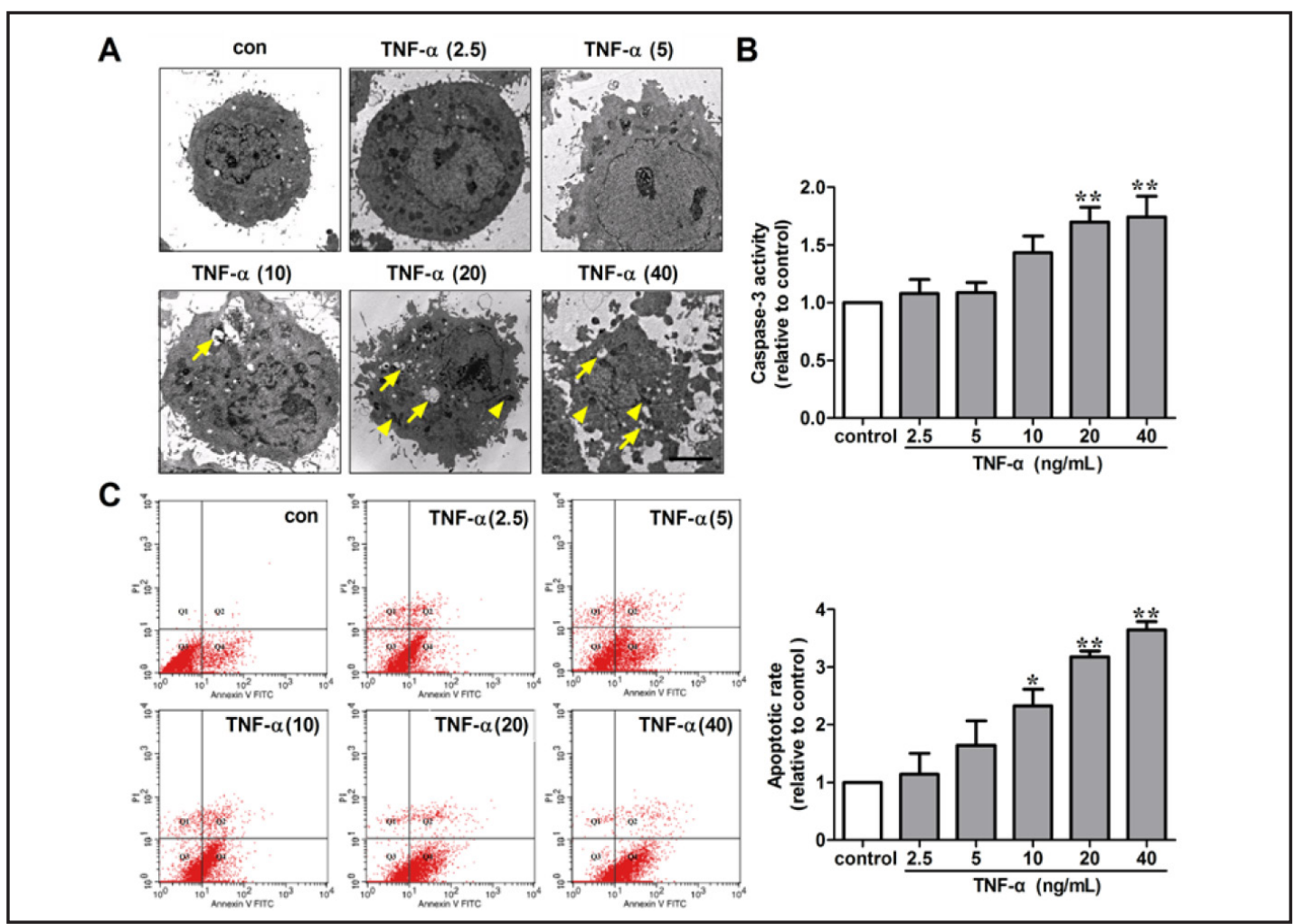

Fig. 1. TNF- $\alpha$ induced ultrastructural injury and apoptosis of H9c2 cells in a dose-dependent manner. TEM analysis of cells exposed to TNF- $\alpha(2.5-40 \mathrm{ng} / \mathrm{mL})$ for $12 \mathrm{~h}$ showing cytoplasmic vacuoles (arrows), apoptotic bodies (arrowheads) and cell membranes dissolution (A). Caspase-3 activity (B) and the percentage of apoptotic cells were evaluated using a caspase- 3 activity assay kit and flow cytometry. Data represent the means \pm SEM $(n=3)$. ${ }^{*} P<0.05$ and ${ }^{* *} P<0.01$ vs. the control group; ${ }^{\#} P<0.05$ and ${ }^{\# \#} P<0.01$ vs. the TNF- $\alpha$ group. Scale bar $=5 \mu \mathrm{m}$. 
A

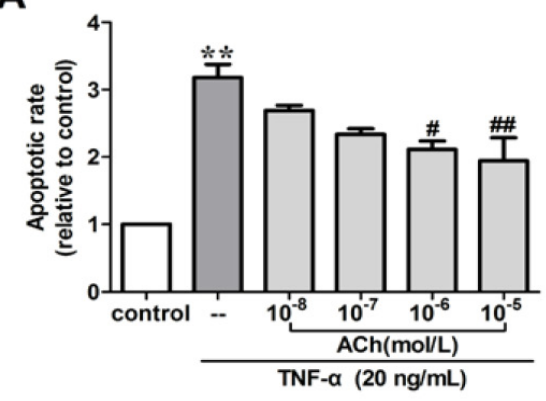

C

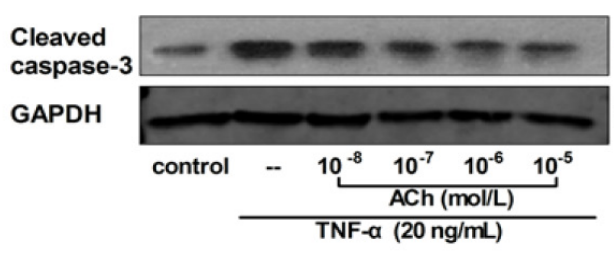

B
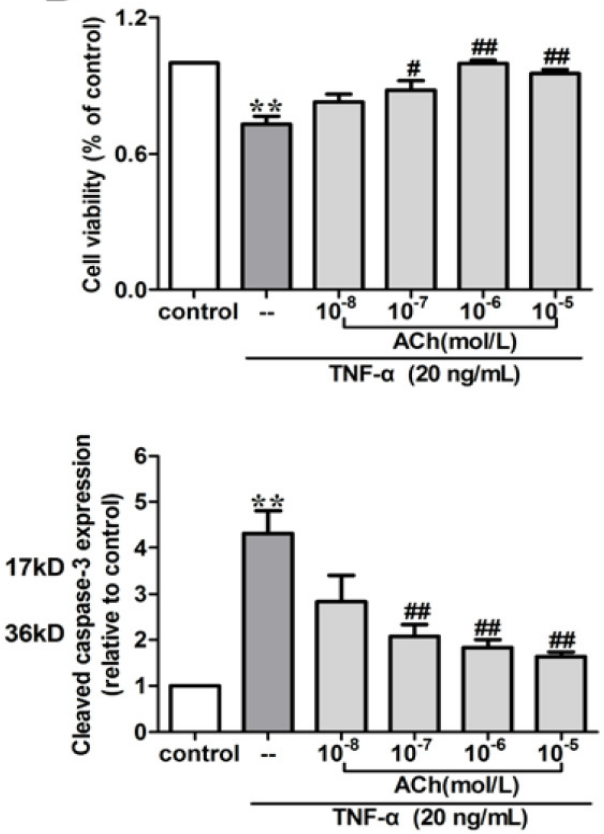

Fig. 2. ACh increased cell viability and decreased TNF- $\alpha$-induced apoptosis. The percentage of apoptotic cells (A), cell viability (B), and cleaved caspase-3 levels in response to different concentrations of ACh $\left(10^{-8}-10^{-5} \mathrm{~mol} / \mathrm{L}\right)$ are shown. The data represent the means $\pm \operatorname{SEM}(\mathrm{n}=3) .{ }^{*} P<0.05$ and ${ }^{* *} P<0.01$ vs. the control group; ${ }^{\#} P<0.05$ and ${ }^{\# \#} P<0.01$ vs. the TNF- $\alpha$ group.

characteristics of apoptosis, including the presence of cytoplasmic vacuoles, cell membrane dissolution, chromatin condensation, and the formation of apoptotic bodies. Based on the caspase-3 activity (Fig. 1B), the percentages of cardiomyocytes in Q4 (early apoptosis) and Q2 (late apoptosis), and the overall percentage of apoptotic cells (Fig. 1C) increased gradually with TNF- $\alpha$ concentration.

ACh increased cell viability and decreased TNF- $\alpha$-induced apoptosis in H9c2 cells

To determine the effect of ACh on cell viability and whether ACh prevents TNF- $\alpha$ induced apoptosis, $\mathrm{H} 9 \mathrm{c} 2$ cells were pretreated with different concentrations of $\mathrm{ACh}\left(10^{-8}-10^{-}\right.$ ${ }^{5} \mathrm{~mol} / \mathrm{L}$ ) for $2 \mathrm{~h}$ and then treated with TNF- $\alpha$ for $12 \mathrm{~h}$. ACh ameliorated apoptosis (Fig. 2A) and the decrease in cell viability (Fig. 2B) induced by TNF- $\alpha$. The TNF- $\alpha$-induced increase in cleaved caspase-3 expression was attenuated by ACh in a dose-dependent manner (Fig. 2C), with ACh $\left(10^{-6} \mathrm{~mol} / \mathrm{L}\right)$ resulting in significant protection of cardiomyocytes. Therefore, we chose $10^{-6} \mathrm{~mol} / \mathrm{L}$ ACh for the following experiments.

The effect of ACh on calpain-1 and calpastatin expression in cardiomyocytes treated with TNF- $\alpha$

H9c2 cells were treated with different concentrations of TNF- $\alpha(2.5-40 \mathrm{ng} / \mathrm{mL})$ for 12 h. Western blots showed that TNF- $\alpha$ increased calpain-1 expression, although it decreased calpastatin expression in a dose-dependent manner (Fig. 3A). Increasing concentrations of ACh $\left(10^{-8}-10^{-5} \mathrm{~mol} / \mathrm{L}\right)$ gradually reversed the changes in the calpain- 1 and calpastatin protein levels induced by TNF- $\alpha$ (Fig. 3C). These results suggested that the calpain/calpastatin system is involved in TNF- $\alpha$-induced cell injury.

Calpain and p38-MAPK signals participated in TNF- $\alpha$-induced apoptosis

H9c2 cells were co-treated with PD150606 (an inhibitor of calpains, $10^{-5} \mathrm{~mol} / \mathrm{L}$ ) or SB203580 (an inhibitor of p38-MAPK, $10^{-5} \mathrm{~mol} / \mathrm{L}$ ) in the presence of TNF- $\alpha$. The Bcl-2/ 


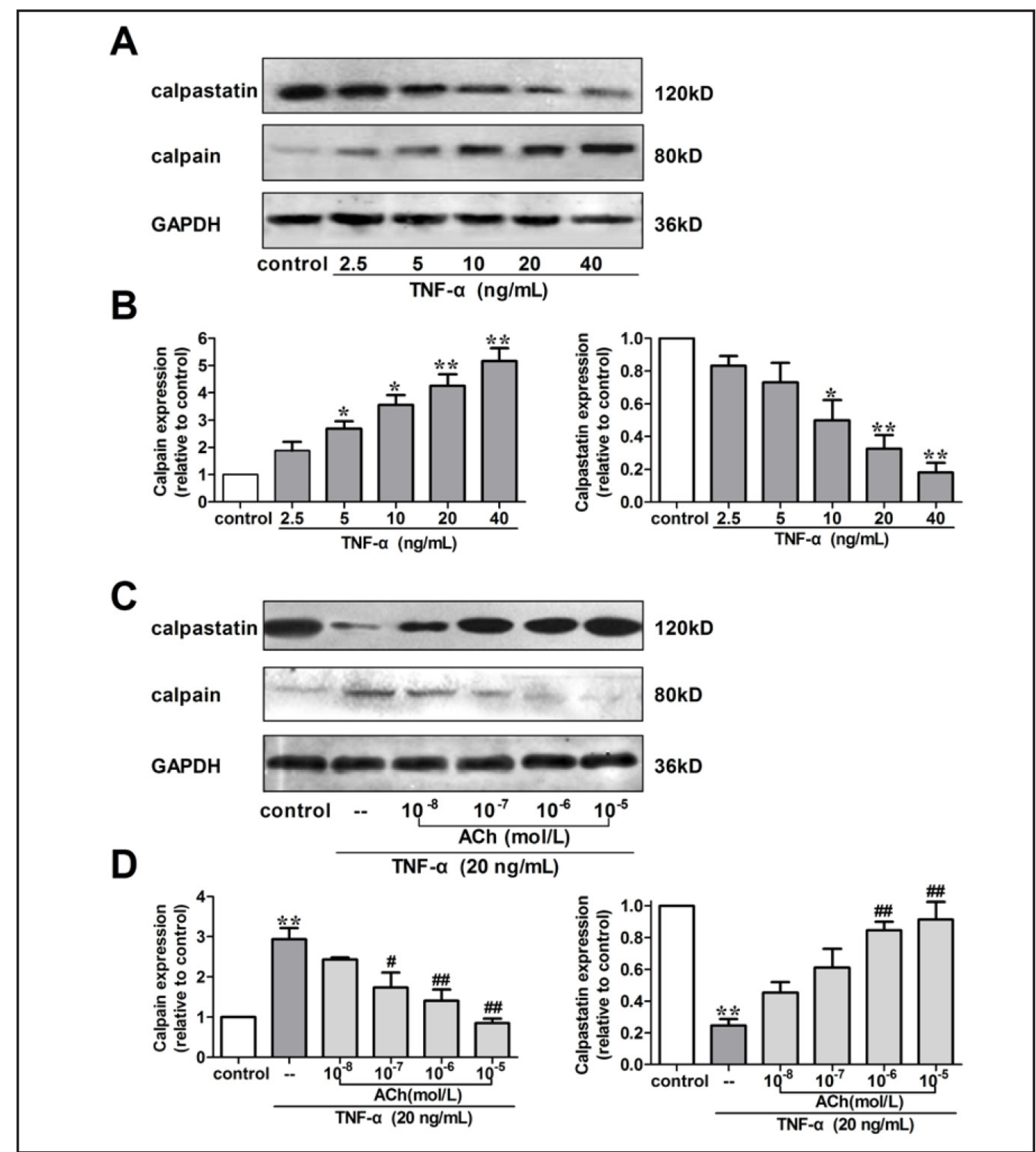

Fig. 3. Protein expression of calpain-1 and calpastatin in cardiomyocytes. The effects of increasing the concentrations of TNF- $\alpha$ (2.5-40 ng/mL) on calpain-1 and calpastatin expression were assessed by Western blotting (A). The effects of ACh $\left(10^{-8}-10^{-5} \mathrm{~mol} / \mathrm{L}\right)$ on TNF- $\alpha$-induced calpain-1 and calpastatin expression in cardiomyocytes (B) are shown. ${ }^{*} P<0.05,{ }^{* *} P<0.01$ vs. the control group. ${ }^{\#} P<0.05$ and ${ }^{\# \#} P<0.01$ vs. the TNF- $\alpha$ group.

Bax ratio (Fig. 4A) and the level of cleaved caspase-3 protein (Fig. 4B) were assessed by Western blotting. The decrease in the Bcl-2/Bax ratio and the increase in cleaved caspase- 3 expression induced by TNF- $\alpha$ were reversed after treatment with PD150606 or SB203580 compared with the TNF- $\alpha$ group.

To investigate the role of p38-MAPK in the TNF- $\alpha$-induced up-regulation of calpain-1, H9c2 cells were co-treated with SB203580 and TNF- $\alpha$, and calpain-1 and calpastatin expression, as well as calpain activity, were assessed. SB203580 inhibited the TNF- $\alpha$-induced up-regulation of calpain-1 and down-regulation of calpastatin in H9c2 cells (Fig. 4C, D and E).

\section{KARGER}




\section{A}

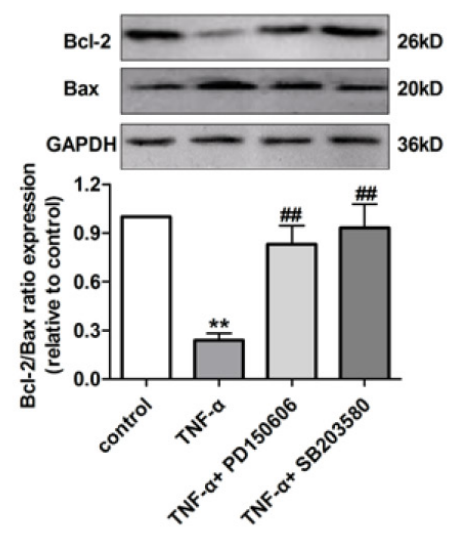

C

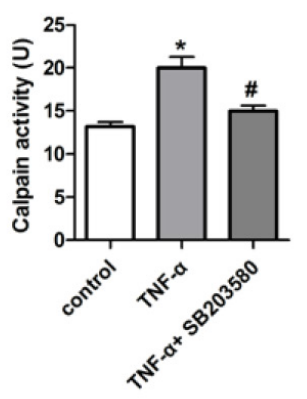

D
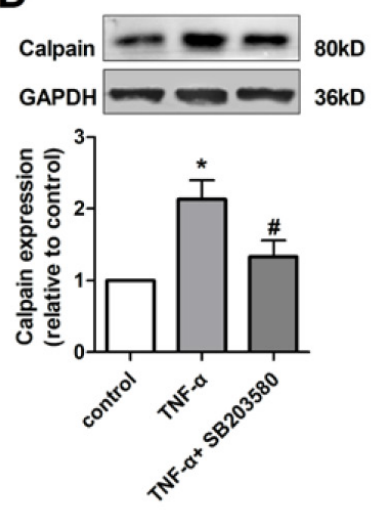

B
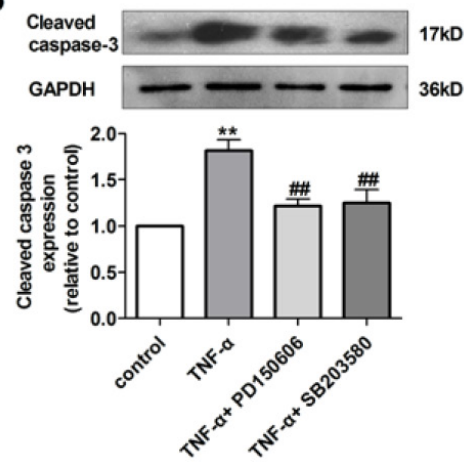

E

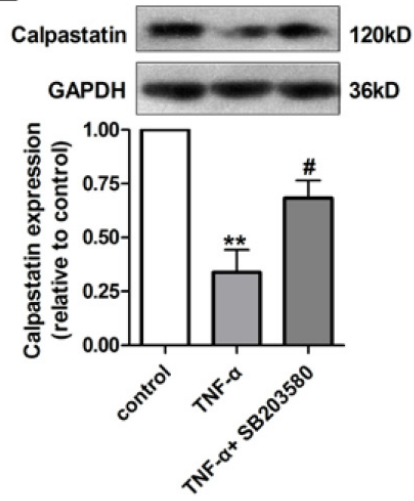

Fig. 4. Calpain-1 and p38-MAPK participates in TNF- $\alpha$-induced apoptosis. (A) Ratio of Bcl-2/Bax protein expression. (B) Cleaved caspase-3 protein levels. (C) Calpain-1 protein expression. (D) Calpain activity. (E) Calpastatin protein expression. ${ }^{*} P<0.05,{ }^{* *} P<0.01$ vs. the control group. ${ }^{\#} P<0.05$ and ${ }^{\# \#} P<0.01$ vs. the TNF- $\alpha$ group.

\section{Muscarinic receptors were responsible for ACh-mediated cardioprotection}

ACh acts on either muscarinic or nicotinic ACh receptors (AChR) to exert its cardioprotective effects [20]. To investigate the cholinergic receptors that play predominant roles in the ACh-mediated suppression of cell injury, atropine (a non-selective muscarinic receptor antagonist, $10^{-6} \mathrm{~mol} / \mathrm{L}$ ) and hexamethonium (a non-selective nicotinic receptor antagonist, $10^{-6} \mathrm{~mol} / \mathrm{L}$ ) were individually combined with TNF- $\alpha$, following pretreatment of H9c2 cardiomyocytes $\left(10^{-6} \mathrm{~mol} / \mathrm{L}\right)$ with ACh. As shown in Fig. 5 , ACh pretreatment significantly inhibited the apoptosis rate in cardiomyocyte, up-regulated the cleaved caspase-3 protein levels and increased the Bcl-2/Bax ratio. These protective effects of ACh were eliminated by atropine but not hexamethonium. Our results suggest that the muscarinic receptor may be responsible for the protective effects of ACh in $\mathrm{H} 9 \mathrm{c} 2$ cells.

\section{Effects of ACh on p38-MAPK and calpain-1 expression}

We determined the effects of ACh on p38-MAPK levels and calpain-1 expression and activity in cardiomyocytes using Western blotting and a calpain activity assay kit. ACh significantly inhibited the TNF- $\alpha$-induced increases in the level of p38-MAPK protein and calpain expression and activity. Interestingly, these effects of ACh were eliminated by atropine, but not hexamethonium, which was in agreement with the apoptosis data (Fig. 6). 


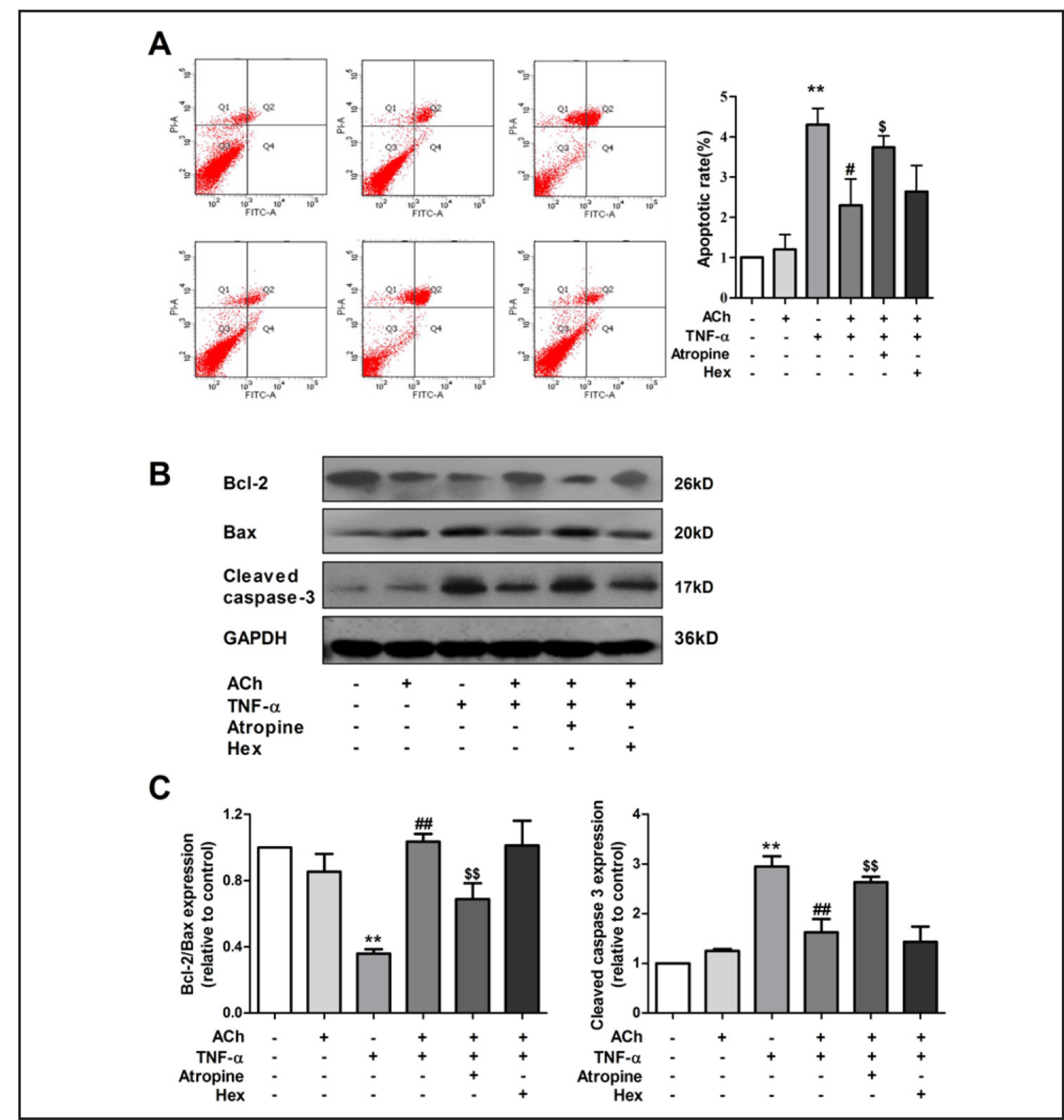

Fig. 5. The muscarinic receptor participates in ACh-mediated cardioprotective effects. (A) Flow cytometry analysis of cardiomyocyte apoptosis. (B) Bcl-2, Bax and cleaved caspase-3 protein expression. ${ }^{*} P<0.05$, ${ }^{* *} P<0.01$ vs. the control group. ${ }^{\#} P<0.05$ and ${ }^{\# \#} P<0.01$ vs. the TNF- $\alpha$ group. ${ }^{\$ \$} P<0.01$ vs. the ACh-treated group.

Knockdown of $M_{2} A C h R$ abolished the anti-apoptotic effect of ACh via calpain-1 and the p38-MAPK signalling pathway

To further determine whether the $\mathrm{M}_{2} \mathrm{AChR}$ is responsible for the beneficial effects of $\mathrm{ACh}$ on the calpain-dependent apoptotic pathway after TNF- $\alpha$ stimulation, we suppressed $\mathrm{M}_{2} \mathrm{AChR}$ expression by transfecting siRNA in $\mathrm{H} 9 \mathrm{c} 2$ cells. As shown in Fig. 7A, $\mathrm{M}_{2} \mathrm{AChR}$ protein expression was down-regulated compared with the corresponding siRNA. The $\mathrm{M}_{2} \mathrm{AChR}$ siRNA efficiently abolished the increase in the Bcl-2/Bax ratio (Fig. 7B) and the attenuation of cleaved caspase-3 expression (Fig. 7C) in the presence of ACh. Furthermore, we assessed the effect of $\mathrm{M}_{2} \mathrm{AChR}$ on the expression of calpain-1 and p38-MAPK in TNF- $\alpha$-stimulated H9c2 cells. Compared with the negative control siRNA group, $\mathrm{M}_{2}$ AChR-depleted cells displayed higher levels of p38-MAPK phosphorylation (Fig. 7D) and calpain-1 expression and activity (Fig. 7E and 7F). These results indicated that the beneficial effects of ACh in the context of TNF- $\alpha$ in H9c2 cells were mainly mediated through $\mathrm{M}_{2} \mathrm{AChR}$. 


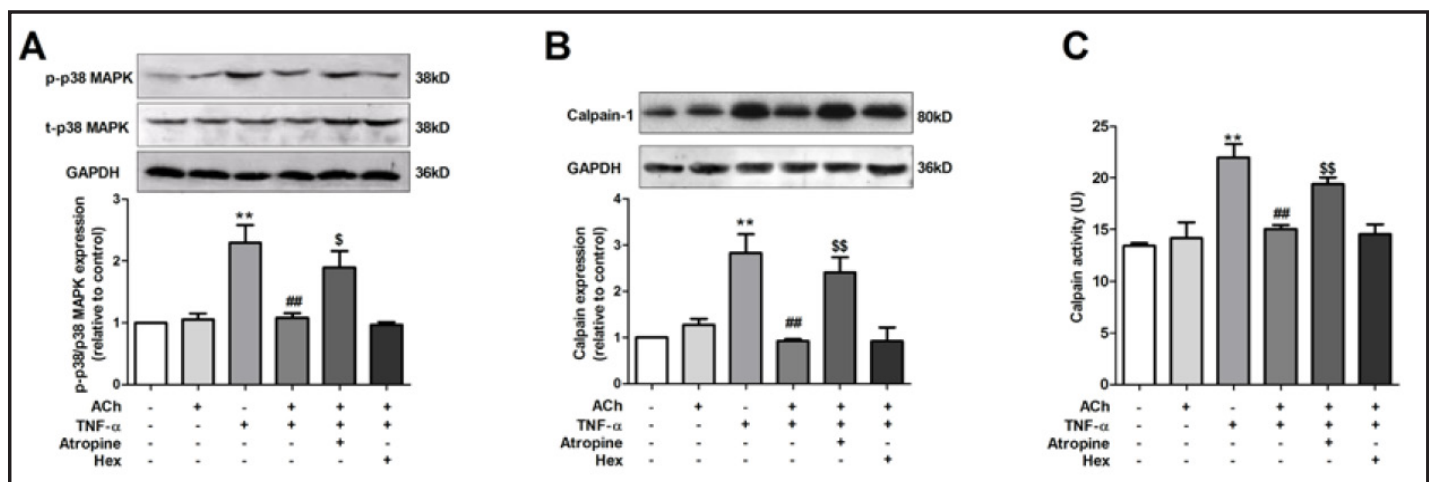

Fig. 6. The effects of ACh on p38-MAPK and calpain-1 expression. (A) p38-MAPK expression and phosphorylation. (B) Calpain-1 and calpastatin protein expression. (C) Calpain activity. ${ }^{*} P<0.05,{ }^{* *} P<0.01$ vs. the control group. ${ }^{\# P}<0.05$ and ${ }^{\# \#} P<0.01$ vs. the TNF- $\alpha$ group. ${ }^{\$} P<0.01$ vs. the ACh-treated group.

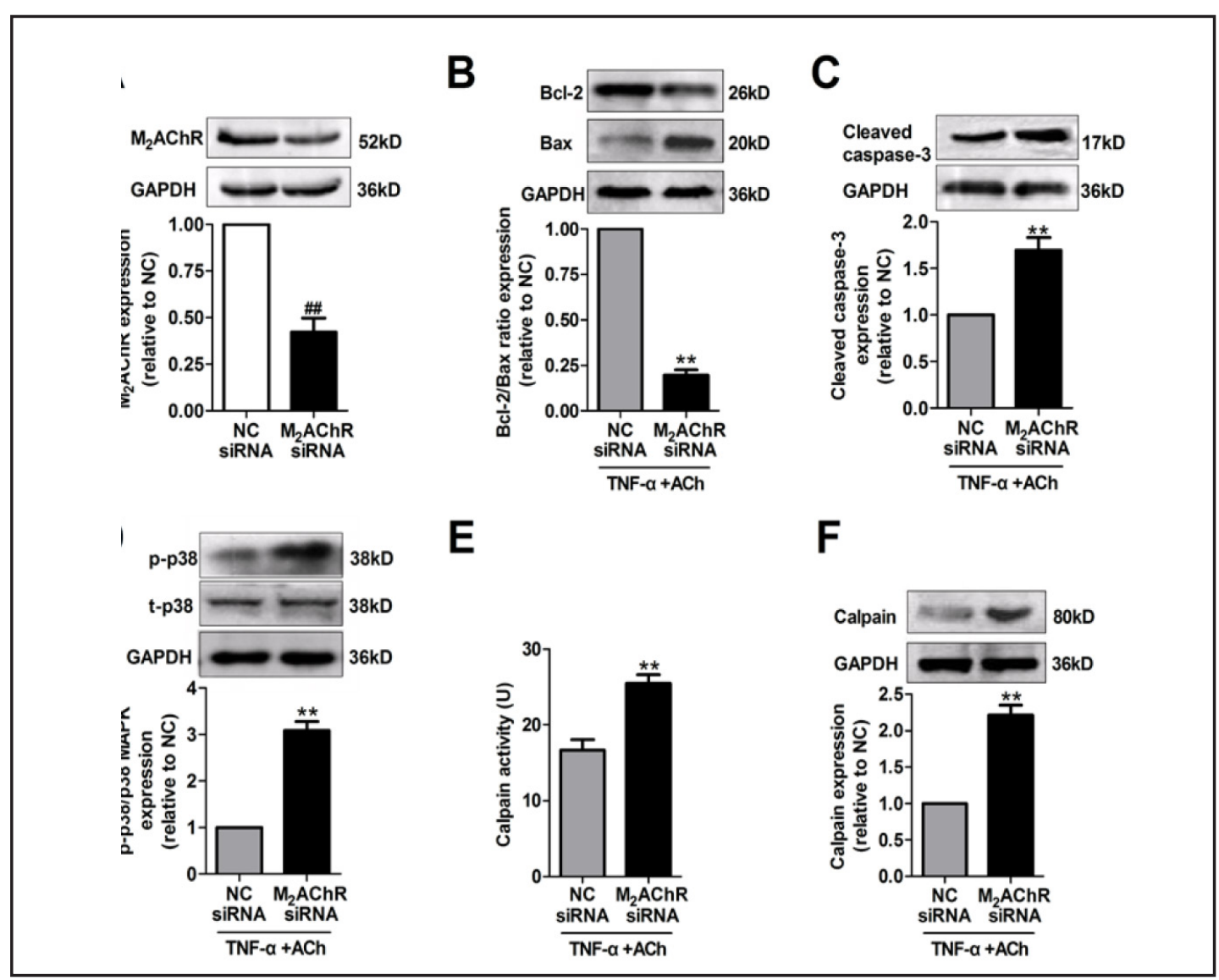

Fig. 7. The role of $M_{2} A C h R$ in TNF- $\alpha$-induced apoptosis in the presence of ACh. (A) The silencing efficiency of $\mathrm{M}_{2} \mathrm{AChR}$ siRNA was detected by Western blotting. (B) The effects of $\mathrm{M}_{2} \mathrm{AChR}$ siRNA on Bcl-2 and Bax protein expression, (C) cleaved caspase-3 protein levels, (D) calpain activity, (E) calpain-1 protein expression, (F) p38-MAPK expression and phosphorylation. ${ }^{\#} P<0.05$ vs. NC siRNA. ${ }^{*} P<0.05,{ }^{* *} P<0.01$ vs. ACh-treated NC SiRNA.

\section{Discussion}

Findings from the present study demonstrated that ACh attenuated TNF- $\alpha$-induced calpain activation by decreasing p38-MAPK phosphorylation and regulating the activity KARGER 
of the calpain/calpastatin system. Our data showed that: ( i ) TNF- $\alpha$ enhanced calpain-1 expression and activity, reduced calpastatin expression, and increased cleaved caspase- 3 protein levels; ( ii ) the p38-MAPK inhibitor SB203580 decreased calpain-1 expression and increased calpastatin expression, decreased the Bcl-2/Bax ratio and enhanced the amount of cleaved caspase-3; (iii) pretreatment with ACh abolished the increases in p38-MAPK phosphorylation, calpain-1 expression and activity, and apoptosis induced by TNF- $\alpha$; ( iv) the protective effects of ACh were abolished by atropine and $\mathrm{M}_{2} \mathrm{AChR}$ siRNA, but hexamethonium failed to cause any changes. Our findings have revealed a novel pathway underlying the cardioprotection elicited by ACh, suggesting that calpain appears to be an important link between inflammatory factors and the control of myocardial cell apoptosis (Fig. 8).

The multifunctional cytokine TNF- $\alpha$ has been implicated in complications arising subsequent to the ischaemic injury of cardiac tissue and diabetic peripheral neuropathy $[21,22]$. Sustained TNF- $\alpha$ over-expression may be maladaptive, provoking the induction of cardiomyocyte apoptosis, which was related to the activation of TNF- $\alpha$ receptor $1[23,24]$. The most widely studied form of intrinsic apoptosis is initiated by the release of cytochrome $\mathrm{C}$ from the mitochondria, resulting in the formation of the apoptosome. The executioner caspase- 3 is activated by the apoptosome, and pro-apoptotic members of the Bcl-2 protein family are activated and act on the mitochondria to induce the release of cytochrome C [25]. Therefore, we attempted to determine whether ACh exerted an effect on the expressions of caspase-3, Bcl-2 and Bax. The present study indicated that TNF- $\alpha$ induced cardiomyocyte apoptosis in a dose-dependent manner. Pre-treatment with ACh dramatically attenuated the up-regulated expression of caspase- 3 and Bax, as well as up-regulating Bcl-2 expression induced by TNF- $\alpha$.

Autonomic dysfunction during cardiovascular disease has serious clinical consequences; thus, improved vagal tone may be a new therapeutic target for the treatment of cardiovascular diseases [26]. Our previous studies reported that vagal stimulation decreased infarct size, improved heart function and ameliorated regional cardiac I/Rinduced endothelial dysfunction in mesenteric arteries through the direct effects of ACh [8, 27]. Administration of ACh prior to hypoxia or reoxygenation reduced apoptosis and the level of inflammatory cytokines in H9c2 cells $[2,6,18]$. In cardiomyocytes, MAChR plays a crucial role in targeting apoptosis inhibition to specific receptor sites [28, 29]. Otherwise, MAChR induces the activation of survival cascades, increased endogenous anti-oxidant reserves, and the reduction of apoptotic mediators such as p38-MAPK during I/R [30]. A recent study showed that an $\mathrm{M}_{2} \mathrm{AChR}$ inhibitor reduced the TNF- $\alpha$-activated endoplasmic reticulum apoptotic pathway via epidermal growth factor receptor-phosphatidyl inositol 3-kinase signalling in cardiomyocytes [19]. Therefore, we co-treated cells with ACh and atropine or hexamethonium in the present study and found that, compared with the AChtreated group, atropine but not hexamethonium augmented cleaved caspase- 3 expression and decreased both the Bcl-2/Bax ratio and cell injury. Moreover, $\mathrm{M}_{2} \mathrm{AChR}$ siRNA abolished the beneficial effects of $A C h$, supporting the role of $\mathrm{M}_{2} \mathrm{AChR}$ in the anti-apoptotic effects of $\mathrm{ACh}$ in $\mathrm{H} 9 \mathrm{c} 2$ cells. The results demonstrated that TNF- $\alpha$-induced apoptosis was inhibited by ACh through $\mathrm{M}_{2} \mathrm{AChR}$.

Calpains belong to a family of calcium-dependent thiol-proteases that has been implicated in several acute inflammatory disorders of the cardiovascular system [29]. A recent study showed that calpain-1 over-expression enhanced myocardial injury and dysfunction within 4 days after coronary occlusion [31]. However, calpain-1 was activated in cardiomyocytes during LPS stimulation, which was inhibited by over-expression of calpastatin and prevented cardiac hypertrophy in angiotensin II-induced hypertension [16]. We detected a marked increase in calpain activity and protein expression and a decrease in calpastatin protein expression in H9c2 cells after TNF- $\alpha$ stimulation. In addition, pharmacological inhibition of calpain (PD150606) prevented cell death in TNF- $\alpha$-stimulated H9c2 cardiomyocytes.

It should be noted that calpain activity can be regulated through phosphorylation by MAPKs, protein kinase C, and protein kinase A [32-34]. MAPKs represent a highly conserved superfamily of serine/threonine protein kinases. There are three well-characterized MAPK

\section{KARGER}


Fig. 8. Schematic illustration of the protective mechanisms of ACh underlying TNF- $\alpha$-induced cardiomyocyte apoptosis. SB203580, p38-MAPK inhibitor; PD150606, calpain inhibitor; atropine, non-selective muscarinic receptor antagonist; ACh, acetylcholine; TNF- $\alpha$, tumour necrosis factor alpha; p38-MAPK, p38-mitogen-activated protein kinase; $\mathrm{M}_{2} \mathrm{AChR}, \mathrm{M}_{2}$ muscarinic ACh receptor.

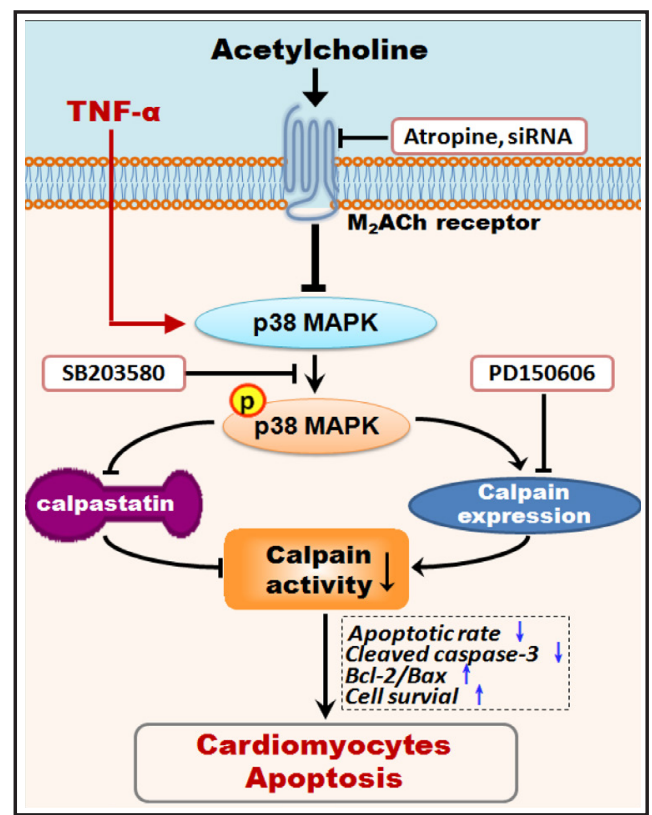

subfamilies: extracellular signal-regulated kinases (ERKs), c-Jun-N-terminal kinases (JNKs) and p38-MAPK [35]. In particular, p38-MAPK is activated by elevated reactive oxygen species (ROS) generation in response to angiotensin II, I/R or hypoxia [36-38]. Chen et al. have reported that pretreatment of cells with TNF- $\alpha$ increased basal and $\mathrm{H}_{2} \mathrm{O}_{2}$-stimulated p38-MAPK expression and cardiomyocyte apoptosis, which was inhibited by SB203580 [39]. Consistent with previous studies, our data showed that TNF- $\alpha$ enhanced the phosphorylation of p38-MAPK and increased calpain protein levels. SB203580 decreased calpain-1 expression and activity, increased the Bcl-2/Bax ratio and calpastatin expression, and decreased the levels of cleaved caspase-3. Our previous studies reported that ACh prevents Ang II-induced apoptosis in H9c2 cells through inhibition of ROS-mediated p38 MAPK activation [7]. Skok et al. thought the $\alpha 7$ nicotinic ACh receptor plays an important role in inhibiting p38-MAPK pathway activation [40]. The data presented here indicated that ACh depressed p38-MAPKdependent intracellular signalling resulting in calpain inactivated via $\mathrm{M}_{2} \mathrm{AChR}$.

In summary, ACh protected cardiomyocytes against TNF- $\alpha$-induced apoptosis by inhibiting p38-MAPK signalling and balancing the activity of the calpain/calpastatin system. Our current studies have shown that ACh elicited beneficial effects via $M_{2} A C h R$ in $H 9 c 2$ cardiomyocytes, confirming the anti-apoptotic effect of ACh in the presence of TNF- $\alpha$ (Fig. 8). The present study provided initial evidence that calpain activation stimulates myocardial apoptosis during inflammation and further revealed that that vagal modulation may represent a promising strategy for the treatment of cardiovascular diseases.

\section{Acknowledgements}

We appreciate the technical support and materials provided by the electron microscopy centre of Xi'an Jiaotong University. This work is supported by National Natural Science Foundation of China (Major International Joint Research Project, No. 81120108002; General Project, No. 81473203 and 81402924), Specialized Research Fund for the Doctoral Program of Higher Education (No. 20130201130008).

\section{Disclosure Statement}

None.

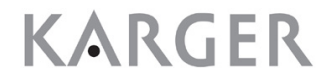




\section{Cellular Physiology Cell Physiol Biochem 2015;36:1877-1889 \begin{tabular}{l|l|l} 
DOI: 10.1159/000430157 & (C) 2015 S. Karger AG, Basel
\end{tabular}

\section{References}

1 Levine B, Kalman J, Mayer L, Fillit HM, Packer M: Elevated circulating levels of tumor necrosis factor in severe chronic heart failure. N Engl J Med 1990;323:236-241.

2 Li DL, Liu JJ, Liu BH, Hu H, Sun L, Miao Y, Xu HF, Yu XJ, Ma X, Ren J, Zang WJ: Acetylcholine inhibits hypoxia-induced tumor necrosis factor-alpha production via regulation of mapks phosphorylation in cardiomyocytes. J Cell Physiol 2011;226:1052-1059.

- 3 Valgimigli M, Ceconi C, Malagutti P, Merli E, Soukhomovskaia O, Francolini G, Cicchitelli G, Olivares A, Parrinello G, Percoco G, Guardigli G, Mele D, Pirani R, Ferrari R: Tumor necrosis factor-alpha receptor 1 is a major predictor of mortality and new-onset heart failure in patients with acute myocardial infarction: The cytokine-activation and long-term prognosis in myocardial infarction (c-alpha) study. Circulation 2005;111:863-870.

-4 Su Q Li L, Zhou Y, Wang J, Liu Y, Ma G: Induction of myocardial pdcd4 in coronary microembolizationrelated cardiac dysfunction: Evidence from a large-animal study. Cell Physiol Biochem 2014;34:533-542.

-5 Liu S, Yin T, Wei X, Yi W, Qu Y, Liu Y, Wang R, Lian K, Xia C, Pei H, Sun L, Ma Y, Lau WB, Gao E, Koch WJ, Wang H, Tao L: Downregulation of adiponectin induced by tumor necrosis factor alpha is involved in the aggravation of posttraumatic myocardial ischemia/reperfusion injury. Crit Care Med 2011;39:1935-1943. M, Sun L, Yu X], Miao Y, Liu J], Wang H, Ren J, Zang W]: Acetylcholine mediates ampk-dependen autophagic cytoprotection in h9c2 cells during hypoxia/reoxygenation injury. Cell Physiol Biochem 2013;32:601-613.

7 Liu JJ, Li DL, Zhou J, Sun L, Zhao M, Kong SS, Wang YH, Yu XJ, Zhou J, Zang WJ: Acetylcholine prevents angiotensin ii-induced oxidative stress and apoptosis in h9c2 cells. Apoptosis 2011;16:94-103. Kong SS, Liu JJ, Hwang TC, Yu XJ, Lu Y, Zang WJ: Tumour necrosis factor-alpha and its receptors in the beneficial effects of vagal stimulation after myocardial infarction in rats. Clin Exp Pharmacol Physiol 2011;38:300-306.

-9 Bajaj G, Sharma RK: Tnf-alpha-mediated cardiomyocyte apoptosis involves caspase-12 and calpain. Biochem Biophys Res Commun 2006;345:1558-1564.

10 Chen Q, Paillard M, Gomez L, Ross T, Hu Y, Xu A, Lesnefsky EJ: Activation of mitochondrial mu-calpain increases aif cleavage in cardiac mitochondria during ischemia-reperfusion. Biochem Biophys Res Commun 2011;415:533-538.

11 Goll DE, Thompson VF, Li H, Wei W, Cong J: The calpain system. Physiol Rev 2003;83:731-801.

12 Moldoveanu T, Hosfield CM, Lim D, Elce JS, Jia Z, Davies PL: A ca(2+) switch aligns the active site of calpain. Cell 2002;108:649-660.

13 Khalil PN, Neuhof C, Huss R, Pollhammer M, Khalil MN, Neuhof H, Fritz H, Siebeck M: Calpain inhibition reduces infarct size and improves global hemodynamics and left ventricular contractility in a porcine myocardial ischemia/reperfusion model. Eur J Pharmacol 2005;528:124-131.

14 Zhang Y, Ren J: New insights of micro-calpain in the pathogenesis of diabetic vascular injury. Diabetes 2015;64:693-695. Smith MA, Schnellmann RG: Calpains, mitochondria, and apoptosis. Cardiovasc Res 2012;96:32-37. Letavernier E, Perez J, Bellocq A, Mesnard L, de Castro Keller A, Haymann JP, Baud L: Targeting the calpain/ calpastatin system as a new strategy to prevent cardiovascular remodeling in angiotensin ii-induced hypertension. Circ Res 2008;102:720-728.

17 Sun L, Zang WJ, Wang H, Zhao M, Yu XJ, He X, Miao Y, Zhou J: Acetylcholine promotes ros detoxification against hypoxia/reoxygenation-induced oxidative stress through foxo3a/pgc-1alpha dependent superoxide dismutase. Cell Physiol Biochem 2014;34:1614-1625.

18 Miao Y, Zhou J, Zhao M, Liu J, Sun L, Yu X, He X, Pan X, Zang W: Acetylcholine attenuates hypoxia/ reoxygenation-induced mitochondrial and cytosolic ros formation in h9c2 cells via $\mathrm{m} 2$ acetylcholine receptor. Cell Physiol Biochem 2013;31:189-198.

19 Miao Y, Bi XY, Zhao M, Jiang HK, Liu JJ, Li DL, Yu XJ, Yang YH, Huang N, Zang WJ: Acetylcholine inhibits tumor necrosis factor alpha activated endoplasmic reticulum apoptotic pathway via egfr-pi3k signaling in cardiomyocytes. J Cell Physiol 2015;230:767-774.

20 He X, Zhao M, Bi X, Sun L, Yu X, Zhao M, Zang W: Novel strategies and underlying protective mechanisms of modulation of vagal activity in cardiovascular diseases. Br J Pharmacol 2014. 


\section{Cellular Physiology Cell Physiol Biochem 2015;36:1877-1889 \begin{tabular}{l|l} 
DOI: 10.1159/000430157 & (c) 2015 S. Karger AG, Basel
\end{tabular} www.karger.com/cpb

21 Tang W, Lv Q, Chen XF, Zou JJ, Liu ZM, Shi YQ: Cd8(+) t cell-mediated cytotoxicity toward schwann cells promotes diabetic peripheral neuropathy. Cell Physiol Biochem 2013;32:827-837.

22 Fragoso Lona JM, Sierra Martinez M, Vargas Alarcon G, Barrios Rodas A, Ramirez Bello J: Tumor necrosis factor alfa in cardiovascular diseases: Molecular biology and genetics. Gac Med Mex 2013;149:521-530.

23 Wallach D, Boldin M, Varfolomeev E, Beyaert R, Vandenabeele P, Fiers W: Cell death induction by receptors of the tnf family: Towards a molecular understanding. FEBS Lett 1997;410:96-106.

24 Packer M: Is tumor necrosis factor an important neurohormonal mechanism in chronic heart failure? Circulation 1995;92:1379-1382.

-25 Portt L, Norman G, Clapp C, Greenwood M, Greenwood MT: Anti-apoptosis and cell survival: A review. Biochim Biophys Acta 2011;1813:238-259.

26 Schwartz PJ, De Ferrari GM: Vagal stimulation for heart failure: Background and first in-man study. Heart Rhythm 2009;6:S76-81.

27 Zhao M, He X, Bi XY, Yu XJ, Gil Wier W, Zang WJ: Vagal stimulation triggers peripheral vascular protection through the cholinergic anti-inflammatory pathway in a rat model of myocardial ischemia/reperfusion. Basic Res Cardiol 2013;108:345.

28 Borroto-Escuela DO, Agnati LF, Fuxe K, Ciruela F: Muscarinic acetylcholine receptor-interacting proteins (machrips): Targeting the receptorsome. Curr Drug Targets 2012;13:53-71.

29 Cuzzocrea S, Chatterjee PK, Mazzon E, Serraino I, Dugo L, Centorrino T, Barbera A, Ciccolo A, Fulia F, McDonald MC, Caputi AP, Thiemermann C: Effects of calpain inhibitor i on multiple organ failure induced by zymosan in the rat. Crit Care Med 2002;30:2284-2294.

-30 Yang B, Lin H, Xu C, Liu Y, Wang H, Han H, Wang Z: Choline produces cytoprotective effects against ischemic myocardial injuries: Evidence for the role of cardiac $\mathrm{m} 3$ subtype muscarinic acetylcholine receptors. Cell Physiol Biochem 2005;16:163-174.

-31 Kang MY, Zhang Y, Matkovich SJ, Diwan A, Chishti AH, Dorn GW, 2nd: Receptor-independent cardiac protein kinase calpha activation by calpain-mediated truncation of regulatory domains. Circ Res 2010;107:903912.

32 Shiraha H, Glading A, Chou J, Jia Z, Wells A: Activation of m-calpain (calpain ii) by epidermal growth factor is limited by protein kinase a phosphorylation of m-calpain. Mol Cell Biol 2002;22:2716-2727.

33 Raynaud F, Jond-Necand C, Marcilhac A, Furst D, Benyamin Y: Calpain 1-gamma filamin interaction in muscle cells: A possible in situ regulation by pkc-alpha. Int J Biochem Cell Biol 2006;38:404-413.

-34 Kennett SB, Roberts JD, Olden K: Requirement of protein kinase c micro activation and calpain-mediated proteolysis for arachidonic acid-stimulated adhesion of mda-mb-435 human mammary carcinoma cells to collagen type iv. J Biol Chem 2004;279:3300-3307.

35 Kyriakis JM, Avruch J: Sounding the alarm: Protein kinase cascades activated by stress and inflammation. J Biol Chem 1996;271:24313-24316.

-36 Moolman JA, Hartley S, Van Wyk J, Marais E, Lochner A: Inhibition of myocardial apoptosis by ischaemic and beta-adrenergic preconditioning is dependent on p38 mapk. Cardiovasc Drugs Ther 2006;20:13-25.

-37 Liu WH, Chang LS: Arachidonic acid induces fas and fasl upregulation in human leukemia u937 cells via ca2+/ros-mediated suppression of erk/c-fos pathway and activation of p38 mapk/atf-2 pathway. Toxicol Lett 2009;191:140-148.

-38 Di Lisa F, Kaludercic N, Paolocci N: Beta(2)-adrenoceptors, nadph oxidase, ros and p38 mapk: Another 'radical' road to heart failure? Br J Pharmacol 2011;162:1009-1011.

39 Chen Z, Jiang H, Wan Y, Bi C, Yuan Y: H(2)o (2)-induced secretion of tumor necrosis factor-alpha evokes apoptosis of cardiac myocytes through reactive oxygen species-dependent activation of p38 mapk. Cytotechnology 2012;64:65-73.

-40 Kalashnyk 0, Lykhmus 0, Oliinyk 0, Komisarenko S, Skok M: Alpha7 nicotinic acetylcholine receptorspecific antibody stimulates interleukin-6 production in human astrocytes through p38-dependent pathway. Int Immunopharmacol 2014;23:475-479. 